Marquette University

e-Publications@Marquette

College of Nursing Faculty Research and

Publications

Nursing, College of

$2-1-2003$

Stage Based Interventions for Low Fat Diet with Middle School Students

Marilyn Frenn

Marquette University, marilyn.frenn@marquette.edu

Shelly Malin

Marquette University

Naveen K. Bansal

Marquette University, naveen.bansal@marquette.edu

Accepted version. Journal of Pediatric Nursing, Vol. 18, No. 1 (February 2003): 36-45. DOI. (C) 2003

Published by Elsevier Inc. Used with permission. 


\title{
Stage-Based Interventions for Low- Fat Diet with Middle School Students
}

\author{
Marilyn Frenn \\ College of Nursing, Marquette University, \\ Milwaukee, WI \\ Shelly Malin \\ College of Nursing, Marquette University, \\ Milwaukee, WI \\ Naveen K. Bansal \\ Department of Math and Statistics, Marquette University, \\ Milwaukee, WI
}

\begin{abstract}
Preventing obesity and cardiovascular disease at early ages is important; however, few effective interventions for early adolescents have been reported. In this study, low-income, culturally diverse students from an urban middle school $(n=60)$ received four classroom interventions with the use of a combined Health Promotion/Transtheoretical Model to control fat in diet and increase physical activity. A control group $(n=57)$ received the usual classroom education. Pretest percentage fat in diet was regressed on demographics, access to low-fat foods, perceived self-efficacy, benefits/barriers, and stage of change with results as proposed by the model $\left[F(9,64)=5.77 ; p=.000 ;\right.$ adjusted $\left.R^{2}=0.35\right]$. Posttest percentage fat in food was significantly less for the intervention group as compared with the control group ( $t=2.06 ; d f, 115 ; p=.04)$.
\end{abstract}


The prevalence of overweight among adolescents tripled in the last 20 years, and these youth have a $70 \%$ chance of becoming overweight or obese adults (National Center for Health Statistics [NCHS], Centers for Disease Control and Prevention, 1999; US Department of Health and Human Services [US DHHS], Office of the Surgeon General, 2001). A healthy diet is important for all persons but is especially important for those at increased risk for having chronic health problems develop as adults, including African American and Hispanic adolescents, and adolescents living in poverty (NCHS, 2001). Among dietary practices, low fat intake appears to be most important in preventing obesity and cardiovascular disease. Because the adverse effects of a high-fat diet accumulate over time, establishing healthy dietary patterns at an early age is important (US DHHS, Public Health Service, 1995; NCHS, 1999).

Helping teens make the transition to adulthood with positive health habits should be a national priority (Velsor-Friedrich, 2001). When compared with early adolescents in other countries, those in the United States have less healthy diets and exercise less frequently (World Health Organization, 2000). Patterns established during middle school years are important in the development of adult health-related habits (Leger \& Nutbeam, 2000). Norms within a young teen's peer group are powerful in shaping behavior, and it is clear that the norms of many teens in the United States do not include healthy eating (Evans, Gilpin, \& Farkas, 1995). Although adolescents can identify healthy food, they often lack the ability or motivation to apply this knowledge in food selection and preparation (Farthing, 1991). Teens, like their parents, consume large amounts of dietary fat (Feunekes, de Graaf, Meyboom, \& van Staveren, 1998).

\section{Theoretical model}

Interventions using components of two behaviorally based research models that have been well tested among adults-the Health Promotion Model (Pender, 1996) and Transtheoretical Model (Prochaska, Norcross, Fowler, Follick, \& Abrams, 1992)-have not been tested regarding low-fat diet with middle school-aged children. Hill (1997) recommended such a study to understand and test interventions that would realistically work in community settings. 
The Health Promotion Model (Pender, 1996) has been used to examine a variety of behaviors leading to a healthy lifestyle. Use of this model has been recommended in adolescent populations (Guthrie, Loveland-Cherry, Frey, \& Dielman, 1994). Those factors most predictive of exercise behavior in early adolescence include demographic variables, self-efficacy, benefits/barriers, and access to behavior requisites (Garcia et al., 1995).

The Transtheoretical Model has been used to examine stage of change for low-fat diet among adults (Auld et al., 1997; Greene, Rossi, Reed, Willey, \& Prochaska, 1994; Lamb \& Joshi, 1996; Read, 1996; Steptoe, Wijetunge, Doherty, \& Wardle, 1996). The constructs incorporated in the Transtheoretical Model include temptation (low self-efficacy), decisional balance (pros and cons), stage, and processes of change.

A combined Health Promotion/Transtheoretical Model guided the intervention design for this study (Figure 1 ).

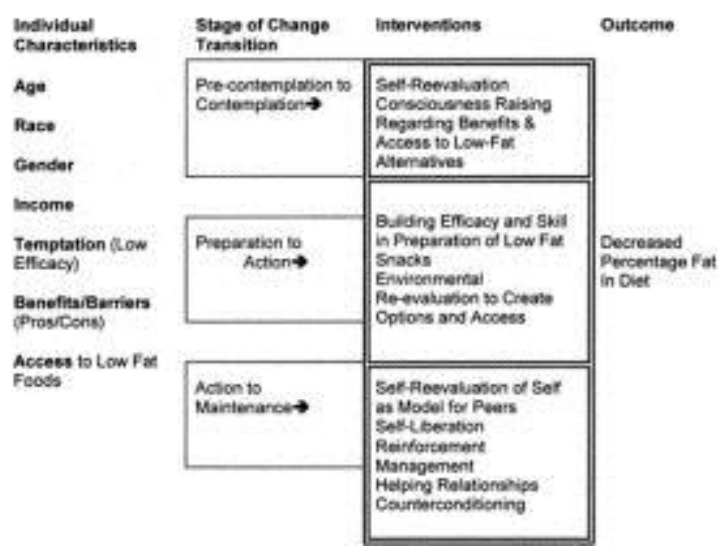

Fig. 1. The health promotion stage of change model: A synthesis of Health Promotion and Transtheoretical Models guiding low-fat diet intervention for students in an urban middle school.

The first individual characteristic examined in this study was temptation (low self-efficacy), defined as the inability to overcome barriers in sustaining a low-fat diet (Velicer, DiClemente, Rossi, \& Prochaska, 1990). McCarthy and Newcomb (1992) posit that the behavioral coping ability of children is usually limited to secondary control because of dependency on their parents and lack of life skills. Lifestyle issues such as drug use peak during ages 13 through 25 
years, so an intervention helping adolescents develop behavioral control may enhance self-efficacy and improve health habits. Use of the Transtheoretical Model with fourth and fifth grade students demonstrated that higher self-efficacy was found among students in the "beyond precontemplation" stage of change for adoption of a diet including recommended amounts of fruits and vegetables (Domel et al., 1996).

The second characteristic common to both the Health Promotion and Transtheoretical Models was benefits/barriers. In a study of fifth through seventh grade children, Baranowski et al. (1990) found the most common barriers to reducing saturated fat in the diet were (a) giving up preferred foods, (b) meals outside the home that contained fat, (c) not knowing what foods were low in fat, and (d) not wanting to take the time to read labels.

The last individual characteristic used in this study was access to low-fat foods. This construct from the Health Promotion Model is important in a middle school-aged population, as they are, to some extent, dependent on others for the types of food available.

Stages of behavior change transition included precontemplation, contemplation, preparation, action, and maintenance. As conceptualized in the Transtheoretical Model, persons in the precontemplation stage are unmotivated. They may "wish" to change to a low-fat diet but have no plans to do so in the next 6 months. Though seriously considering a low-fat diet, persons in the contemplation stage have no specific plans to begin such a change. Those in the preparation stage are making small changes such that intention and behavior are combined. For example, persons who state the intention to change within 1 month and/or have a prior unsuccessful attempt within the last year are in preparation. The action stage includes persons who have been actively engaging in a low-fat diet for 1 day to 6 months. Persons are considered to be in the maintenance stage when they have sustained a change for 6 months or more.

Research findings indicate that persons use or respond to different processes of change pertinent to each stage (Table 1). 
NOT THE PUBLISHED VERSION; this is the author's final, peer-reviewed manuscript. The published version may be accessed by following the link in the citation at the bottom of the page.

Table 1. Definitions of processes of change useful in each stage of change

$\begin{array}{ll}\begin{array}{l}\text { Stage of Change } \\ \text { Precontemplation } \\ \text { Contemplation }\end{array} & \begin{array}{l}\text { Processes Useful } \\ \text { Consciousness raising* } \\ \text { Self reevaluation* }\end{array} \\ \begin{array}{ll}\text { Preparation } & \text { Self-liberation } \\ \text { Coction } & \text { Stimulus control } \\ & \text { Reinforcement* } \\ & \text { management } \\ & \text { Helping Relationships }\end{array}\end{array}$

Dramatic relief

Environmental* reevaluation Social liberation

\section{Definition}

Increasing information about dietary fat

Assessing how one feels and thinks about how much fat one is eating

Choosing to limit fat to $20 \%-30 \%$ of calories

Substituting other activities or low-fat for high-fat foods

Avoiding high-fat foods or cues to eat them

Rewarding self or being rewarded for making changes to bring fat to $20 \%-30 \%$ of calories

Being open about problems, engaging in self-help groups, and identifying and fostering social support

Experiencing and expressing problems and solutions (e.g., through focus groups, role playing)

Assessing environment for how individual choices may affect others' choices of fat in foods

Advocating for availability of low-fat food choices

*Useful across all stages of change.

Researchers measuring the stage of change repeatedly find that, across health behaviors, most persons are in the precontemplation or contemplation stage (Prochaska et al., 1994). According to Prochaska, DiClemente, and Norcross (1992), two processes used in those early stages of change, consciousness raising and self reevaluation, continue to be used in varying degrees across all stages.

In contrast, the remaining action-oriented processes of change are used in the preparation, action, and maintenance stages of change. For example, cardiac patients who were in the preparation or action phase of quitting smoking improved $94 \%$. The same actionoriented program made no difference for those in the precontemplation or contemplation phase. Thus, according to Prochaska et al. (1994), if we approach schools or other sites with only action-oriented programs, we likely will underserve or fail to serve the majority of persons. The purpose of this study was to examine the effectiveness of a 4-session Health Promotion/Transtheoretical Modelguided intervention in reducing percentage fat in diet and increasing physical activity among low- to middle-income, culturally diverse middle school students. 
NOT THE PUBLISHED VERSION; this is the author's final, peer-reviewed manuscript. The published version may be accessed by following the link in the citation at the bottom of the page.

\section{Literature review}

Over the past 15 years, numerous studies have been conducted in which researchers have attempted to alter knowledge, attitudes, and behavior of children and adolescents with regard to healthy diets. Extensive reviews of research (Contento et al., 1995; Meininger, 1997; Kennedy, 1998) revealed many studies in which nutrition knowledge and attitudes of children were improved. These reviews were helpful in demonstrating that school-based interventions were more effective than interventions conducted outside of the school setting. Despite the inability to randomly assign individual subjects to groups, schools offer an ideal setting in which to intervene in an effort to promote the health of teens for many reasons, including access to large numbers of students (Taylor, 2000).

School-based programs to modify physical activity and nutrition behaviors have not always been successful in lowering body weight, blood pressure, or cholesterol (Luepker et al., 1996). However, promising results have been demonstrated with elementary school children, including increased knowledge, decreased body fat, and decreased blood cholesterol levels (Harrell et al., 1998). Current research by Harrell et al. is under way to determine whether similar approaches will be effective and sustained with middle school students. The successful results at the elementary level required the hiring of an additional physical education teacher in each study school. Given concerns about academic proficiency and school costs (Williams, 1999), we must continue to explore additional methods of effectively helping early adolescents to reduce dietary fat that are feasible and cost-effective.

The only published report of effective intervention with students in a middle school setting (Gortmaker et al., 1999) demonstrated a reduced prevalence of obesity in girls, reduced time viewing television, and increased fruit and vegetable consumption among girls and boys. Gortmaker et al. included 16 core lessons for each of 2 academic years, implemented in 4 sessions during each of several academic classes. The core lessons were supplemented by 8 mini-lessons of 5 minutes each during physical education classes. The schools included were located in zip codes with the lowest income for that state, 
although that level was at the national mean income level. The study sample included $17 \%$ African American girls in the control versus $10 \%$ in the intervention group and $18 \%$ versus $12 \%$ Hispanic boys, respectively. Obesity in African American girls was significantly reduced, but the results for Hispanics were insignificant (Gortmaker et al., 1999). Although ethnicity was controlled for in the regression analyses, the study sample did not reflect the demographics of those who become most at risk for obesity as they grow into adulthood, namely African American and Hispanic women and those with low income (NCHS, 1999).

Even though there have been many studies testing interventions in schools, only one study examining utilization of tested interventions was found. In this study 17 sessions were included in the original research, whereas use of the intervention was limited to 6 sessions delivered by teachers in practice (Lewis, Brun, Talmage, \& Rasher, 1988). Short-term interventions thus need to be tested if we hope to promote teachers' use of them in schools. We have tested a theoretically based short-term intervention in the current study.

\section{Current study}

The following research questions guided this study: (a) Do demographic variables, access to low-fat foods, perceived self-efficacy, benefits/barriers, and stages of change predict percentage of fat reported in the diet by middle school-aged children? (b) Does the application of a Health Promotion/Transtheoretical Model intervention in 4 classroom sessions significantly improve adoption of a diet lower in fat and duration of physical activity as compared with a control group of students not engaged with the program?

\section{Method}

A quasiexperimental design was used. Students were randomly assigned to academic "families" when they entered the school. Members of academic families had separate classes and teachers. The school was selected because the concept of academic families helped prevent diffusion of the intervention to the control group. However, 
the classroom-based intervention did not permit random assignment of students to the intervention or control groups.

\section{Setting and sample}

A central city middle school serving low-income, culturally diverse students was the setting for the study. After parental consent was obtained, sixth, seventh, and eighth grade students from two mutually exclusive academic "families" within the school were invited to participate in (a) a stage of change classroom intervention or (b) the usual school conditions. Of the possible 220 students in the two academic families, 182 individual students participated, for a $91 \%$ response rate. List-wise deletion used in multivariate analysis meant that 74 subjects were included for whom complete data were available on all instruments. For the total sample, female students comprised $52 \%$ of the sample and male students $47 \%$ (1\% missing demographic data). Because middle school-aged children usually do not know their family income, income was estimated by asking students their zip code and determining mean per capita by race income from the census data. The mean income for the sample was $\$ 8089$, with $50 \%$ composed of African American, 20\% Caucasian, 14\% Hispanic, and $15 \%$ other races. The students' mean age was 13.82 years (SD, 1.14 years; range, 12-17 years).

\section{Measures}

The combined Health Promotion/Transtheoretical Model is depicted in Figure 1. The access to healthy foods questionnaire was modeled after an exercise access instrument for adolescents within the Health Promotion Model (Garcia et al., 1995). It contained 9 items with a 5-option Likert scale regarding availability of low-fat foods. A higher score indicates greater access to low-fat foods. The a coefficient in this study was. 81 .

Because Transtheoretical Model measures were developed for use with adults, experts working with adolescents reviewed the instruments used in this study for cultural and developmental appropriateness. With use of items from Frenn and Porter's qualitative study (1999) and with consultation from Pender and Prochaska et al., 
revised instruments were developed, refined with focus groups, and tested with culturally diverse, low- to middle-income middle school students before this study.

The temptation scale for low-fat foods is being used in high school students in a funded study currently being conducted at the University of Rhode Island, Providence, Rhode Island. The higher the score, the greater the temptation to eat high-fat foods (lowest selfefficacy). The coefficient a for the 7 -item scale was.86 in the present study.

The benefits (pros) and barriers (cons) of eating a diet with $30 \%$ or fewer calories from fat were measured with the Decisional Balance Questionnaire (DBQ). The "cons" portion of the instrument was reverse-scored for purposes of analysis. A prior study $(N=119)$ with the DBQ indicated that satisfactory internal consistency estimates could be maintained if it was reduced in number of items. However, in the present study, the a coefficients were.81 for the 5 -item pros and.61 for the 4 -item cons portions of the instrument.

Staging questions used by Greene, Rossi, Reed, Willey, and Prochaska (1994) were used with the following modification: instead of asking about 6 months ago, anchors such as "at the beginning of the school year" were used to help students think about how much fat they were eating 6 months ago. The staging instrument includes 7 items: the first question uses a 5-option Likert scale regarding intention to avoid eating high-fat food in the next 6 months. The next 5 items include "yes"/"no" options regarding selected high- and low-fat foods consumed. The seventh question is the staging question used for analysis: subjects report the length of time they have been eating lowfat foods or when they intend to start. Students describing themselves in the action or maintenance stages of change were re-staged to precontemplation if their fat intake exceeded 30\% according to the Rossi et al. (1994) algorithm. Because of the amount of class time needed for both instrument administration (one class session before and after) and intervention, processes of change were not measured in this study.

The Food Habits Questionnaire was used to measure percentage fat in diet (Greene et al. 1994). This instrument includes a 21-item permission has been granted for this version to appear in e-Publications@Marquette. Elsevier (WB Saunders) does not grant permission for this article to be further copied/distributed or hosted elsewhere without the express permission from Elsevier (WB Saunders). 
series of questions about frequency of consumption of high- and lowfat foods with a 5-option response format. Low-fat items were reversescored and an algorithm used to calculate percentage of fat such that the resulting total score indicated percentage of fat in food consumed during the last month. The a coefficient was. 87 in this study sample.

The Child and Adolescent Activity Log (CAAL) was used to collect the physical activity data. Students were asked to check activities they had done during the previous day for each of 7 days and to circle the amount of time spent on each. The CAAL contains 21 activities commonly engaged in by early adolescents and previously was found to correlate highly with exercise as measured by Caltrac accelerometers (BIO/ANALOGICS, Beaverton, OR) and with fitness as measured by a step test (Garcia et al., 1995). Similar to the study of Garcia et al., in this study students who had completed at least 3 days of log data were included in the analysis of average weekly duration of physical activity.

\section{Procedures}

After review for protection of human subjects, a letter was sent home to parents explaining the study. Parents who did not want their children to participate were asked to inform the Family and Consumer Education (FACE) teacher. Two students thus excluded completed other assignments during data collection. All remaining students agreed to participate and completed the following instruments: demographic information, temptation scale to measure efficacy regarding dietary fat, DBQ to measure pros and cons regarding dietary fat consumption, low-fat diet stage of change instrument, access to low-fat food, Food Habits Questionnaire, and CAAL.

All classroom interventions took place during the FACE class, as this fit best within the school curriculum. As shown in Table 2, the primary classroom strategy for these 45-minute sessions was consciousness raising and self-reevaluation, because the majority of students were in the precontemplation or contemplation stage of change and these processes are appropriate interventions in later stages as well (Prochaska, DiClemente, \& Norcross, 1992).Separate smaller group sessions, which used appropriate processes of change (Table 2), were held for students in the preparation, action, and permission has been granted for this version to appear in e-Publications@Marquette. Elsevier (WB Saunders) does not grant permission for this article to be further copied/distributed or hosted elsewhere without the express permission from Elsevier (WB Saunders). 
NOT THE PUBLISHED VERSION; this is the author's final, peer-reviewed manuscript. The published version may be accessed by following the link in the citation at the bottom of the page.

maintenance stages of change. Graduate nursing students in pediatric nursing implemented the classroom and small group interventions developed by the investigators using the Health Promotion/Transtheoretical Model. Investigators attended all sessions to ensure consistency across presenters.

Table 2. Intervention session descriptions based on stage and processes of change

Session

1

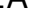

$A^{*}$ planning low-fat snack session ( $\mathrm{CR}, \mathrm{SL})$

2 Personal food diary review, better choices in fast food restaurants (SR)

2A* Peer leadership for large group snack session (CC, SC, HR, SL)

3 Low-fat snacks (CR, SR)

3A* Planning large group exercise that is fun and easily done by all

$4 \quad$ Exercise for healthy life (CR, SR)

4A* Evaluation, focus group session (RM, DR, ER)

\section{Activity}

Use of concrete, age-specific examples; poster review; brainstorming of benefits/barriers to low-fat diet

Play game; begin discussion of snacks to prepare in classroom

Discuss food diary and fat content on snack wrappers and fast food restaurant menus

Select snacks; create shopping lists for recipes and rehearse roles for large group session

Preparation and sampling of 4 snacks; review recipes with emphasis on fat content

Choose exercise stations; create posters for station including calories burned in 5 minutes

Peers lead 5 exercise stations

Discuss sessions and knowledge gained regarding: low-fat diets, exercise, and self as leader

*Included subgroup of students in preparation, action, or maintenance stage of change.

Abbreviation: $\mathrm{CR}$, consciousness raising; $\mathrm{SR}$, self reevaluation; $\mathrm{CC}$, counterconditioning; $\mathrm{SC}$, stimulus control; RM, reinforcement management; HR, helping relationships; DR, dramatic relief; ER, environmental reevaluation; SI, social liberation.

Only 4 classroom intervention sessions (as well as 4 small group sessions for students in the preparation, action, and maintenance stages of change) were planned because the FACE class time was also needed for other curricular content. Classroom interventions incorporated processes appropriate for the precontemplation and contemplation stages of change by using multiple instructional methods appropriate to middle school students, content to increase

Journal of Pediatric Nursing, Vol 18, No. 1 (2003, February): pg. 36-45. DOI. This article is (c) Elsevier (WB Saunders) and permission has been granted for this version to appear in e-Publications@Marquette. Elsevier (WB Saunders) does not grant permission for this article to be further copied/distributed or hosted elsewhere without the express permission from Elsevier (WB Saunders). 
knowledge, and peer modeling of skills (Table 2). Students in the preparation, action, and maintenance stages of change used processes appropriate to these stages during small group work as they prepared to be peer models for other students in their classrooms.

Students in both the control and intervention groups received all measures as a paper-and-pencil test at the beginning and end of the study period. Pre- and post-evaluation data were collected by data collectors trained by the project coordinators. Data collectors were "blind" as to whether the groups experienced the intervention or served as the control group. Fruit snack rewards were given as instruments were completed.

\section{Analysis}

Data were first analyzed to determine whether there were differences between the intervention and control group before testing with SPSS for Windows, version 9 (SPSS Inc, Chicago, IL), $X^{2}$ for nominal-level variables and multiple analysis of variance for intervallevel data as recommended by Foster (2001). Relationships among the variables thought to predict a diet lower in fat were then examined by linear regression. Difference scores were computed by subtracting pretest from posttest values, and means of intervention and control groups were compared with use of a $t$ test for independent samples as recommended by Foster (2001).

\section{Results}

There were no significant differences $(p<.05)$ on any demographic variables or on percentage fat in diet or duration of physical activity between the intervention and control groups before testing. As shown in Table 3, antecedents predicting a diet higher in fat before testing were in the direction proposed by the Health Promotion/Transtheoretical Model.Higher stage of change (i.e., action or maintenance as compared with precontemplation) was inversely related to a diet higher in fat $(\beta=-.496 ; p=.000)$. Higher temptation (low self-efficacy) was positively related to consumption of high-fat foods ( $\beta=.242 ; p=.02$ ). Although not statistically significant, access to low-fat foods was inversely related to high-fat food consumption, as 
NOT THE PUBLISHED VERSION; this is the author's final, peer-reviewed manuscript. The published version may be accessed by following the link in the citation at the bottom of the page.

were "pros," or benefits of choosing a low-fat diet. "Cons," or barriers, were positively related to a diet high in fat.

Table 3. Regression of antecedents predicting higher fat in diet before testing Standardized Coefficients

\begin{tabular}{|c|c|c|c|c|}
\hline Antecedent & $\boldsymbol{\beta}$ & $\boldsymbol{t}$ & & Significance $(p)$ \\
\hline Constant & & 9.386 & .000 & \\
\hline Access to low-fat foods & -.116 & -0.985 & .328 & \\
\hline Stage for low fat ${ }^{a}$ & -.496 & -4.472 & .000 & \\
\hline Low fat efficacy total & .242 & 2.358 & .021 & \\
\hline Cons low fat total & .072 & 0.684 & .497 & \\
\hline Pros low fat total & -.097 & -0.804 & .424 & \\
\hline Gender $^{\mathrm{b}}$ & -.034 & -0.352 & .726 & \\
\hline Income $^{c}$ & -.025 & -0.234 & .816 & \\
\hline Age $^{d}$ & -.089 & -0.897 & .373 & \\
\hline Race $^{e}$ & -.095 & -0.917 & .363 & \\
\hline
\end{tabular}

aStages coded as follows: 1 , precontemplation $(n=25)$; and 2 , contemplation $(n=$ $27)$; 3, preparation $(n=11) ; 4$, action $(n=5)$; and 5 , maintenance $(n=6)$. bender coded as follows: 1 , male $(n=31)$; and 2 , female $(n=43)$. 'Income based on census per capita income by race for zip code (mean, $\$ 8,089 ;$ range, $\$ 3,985-\$ 19,581$ ). ${ }^{\mathrm{d}} \mathrm{Age}$ (in years); $17(n=1) ; 16(n=6) ; 15(n=10) ; 14(n=30) ; 13(n=16)$; and $12(n$

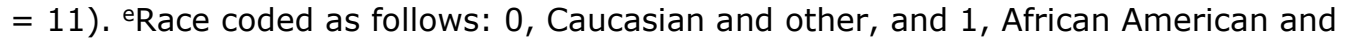
Hispanic.

Dependent variable, percentage fat in food: $\left[F(9,64)=5.36 ; p=.000 ;\right.$ adjusted $R^{2}=$ $0.35]$

None of the multivariate or univariate tests for differences in study variables based on demographic variables were significant for this sample. Because several cells had expected frequencies lower than 5, making interpretation difficult, $\mathrm{X}^{2}$ differences in demographic variables by stage are not reported here.

The multiple analysis of variance in which study variables were examined for differences by stage of change was significant $(p=.000)$. Significant univariate differences by stage also were found, as shown in Table 4. 
NOT THE PUBLISHED VERSION; this is the author's final, peer-reviewed manuscript. The published version may be accessed by following the link in the citation at the bottom of the page.

Table 4. Health promotion/transtheoretical model variables by stage of change for low fat before testing

\begin{tabular}{|c|c|c|c|c|c|c|c|c|c|c|}
\hline \multirow[b]{2}{*}{ Variable } & \multicolumn{2}{|c|}{$\begin{array}{l}\text { Precontemplation } \\
\text { (PC) }(n=47)\end{array}$} & \multicolumn{2}{|c|}{$\begin{array}{l}\text { Contemplation } \\
\text { (C) }(n=44)\end{array}$} & \multicolumn{2}{|c|}{$\begin{array}{l}\text { Preparation } \\
\text { (P) }(n=30)\end{array}$} & \multicolumn{2}{|c|}{$\begin{array}{c}\text { Action (A) } \\
(n=12)\end{array}$} & \multicolumn{2}{|c|}{$\begin{array}{l}\text { Maintenance } \\
\text { (M) }(n=12)\end{array}$} \\
\hline & Mean & SD & Mean & SD & Mean & SD & Mean & SD & Mean & SD \\
\hline $\begin{array}{l}\text { \% Fat in } \\
\text { diet }\end{array}$ & 32.44 & 2.57 & 31.77 & 2.73 & 29.86 & $2.27 * *$ & 28.07 & $1.30 *$ & 27.31 & $1.82^{\mathrm{a}}$ \\
\hline Access & 28.74 & 8.01 & 29.36 & 6.39 & 32.49 & 5.00 & 35.56 & 6.93 & 36.50 & $6.25^{b}$ \\
\hline $\begin{array}{l}\text { Pros } \\
\text { (benefits) }\end{array}$ & 13.75 & 5.22 & 15.59 & 5.09 & 17.88 & 5.00 & 18.44 & 5.09 & 20.12 & $3.79^{c}$ \\
\hline $\begin{array}{l}\text { Cons } \\
\text { (barriers) }\end{array}$ & 14.64 & 4.12 & 15.69 & 4.43 & 14.89 & 4.04 & 13.62 & 4.00 & 14.00 & 4.07 \\
\hline $\begin{array}{l}\text { Temptation } \\
\text { (low self- } \\
\text { efficacy) }\end{array}$ & 25.72 & 7.43 & 25.73 & 7.08 & 24.29 & 7.39 & 26.53 & 7.98 & 24.71 & 5.79 \\
\hline $\begin{array}{l}* p=.03, \text { sic } \\
\text { stage. aTuk } \\
\text { bTukey sign } \\
\text { and } A(p=.\end{array}$ & $\begin{array}{l}\text { gnificantly } \\
\text { ey signific } \\
\text { ificantly g } \\
.02 \text { ) and }\end{array}$ & y greate & een PC & $\mathrm{PC}$ ( $(p=$ & $=02)$ & $\begin{array}{l}=.02) \text { an } \\
\text { between }\end{array}$ & d bet & d M $(p$ & $\begin{array}{l}\text { and } M \\
=.02) \text {, }\end{array}$ & $\begin{array}{l}\text { us } \\
=.03) \text {. } \\
\text { tween } \mathrm{C} \\
\text { and } \mathrm{A}\end{array}$ \\
\hline
\end{tabular}

The average percentage of fat in food ranged from $30.7 \%$ to $32.8 \%$, with the intervention group increasing percentage of fat to a lesser extent than the control group $(t=2.018 ; d f, 99 ; p=.046)$. Duration of exercise also was significantly higher for the intervention group than the control group $(t=2.925 ; d f, 81 ; p=.004)$ after the intervention.

\section{Discussion}

Health Promotion/Transtheoretical Model variables accounted for $35 \%$ of the variance in percentage of fat reported in the diet by middle school-aged children, as shown in Table 3 . Congruent with the model, temptation (low self-efficacy) and being in an earlier stage of change significantly predicted a diet higher in fat.

Most importantly, the percentage of fat in the diet decreased significantly across stages. The significant differences in self-efficacy and percentage of diet from fat across stages of change provide evidence that the Health Promotion/Transtheoretical Model appropriately classifies culturally diverse middle school students from families with low per capita income relative to dietary fat.

Journal of Pediatric Nursing, Vol 18, No. 1 (2003, February): pg. 36-45. DOI. This article is @ Elsevier (WB Saunders) and permission has been granted for this version to appear in e-Publications@Marquette. Elsevier (WB Saunders) does not grant permission for this article to be further copied/distributed or hosted elsewhere without the express permission from Elsevier (WB Saunders). 
NOT THE PUBLISHED VERSION; this is the author's final, peer-reviewed manuscript. The published version may be accessed by following the link in the citation at the bottom of the page.

Interestingly, access to low-fat foods also increased significantly across stages of change, identifying the importance of access in the lives of early adolescents who are often dependent on others for healthy food options. The Health Promotion Model variable has not been reported in conjunction with the Transtheoretical Model before but addresses a critical deficit of the latter model when used alone. Pros (construed as benefits in the Health Promotion Model) also increased significantly across stages of change (and with decreasing dietary fat), as is predicted within both models.

Tukey post hoc analyses demonstrated that significant differences occurred between precontemplation and action, as well as precontemplation and maintenance, for pros (benefits), access, and fat in food (Table 3). Differences were also significant for the access variable between contemplation and action, as well as between contemplation and maintenance. It appears that a component of preparation (which occurs between contemplation and action) is to consider benefits (pros) and increase access to low-fat foods while making small changes in reducing fat, such that significant changes in fat intake occur in the action and maintenance stages.

When the Health Promotion/Transtheoretical Model interventions were used in 4 classroom sessions, students had a significantly ( $p$ $<.05)$ reduced trend toward choosing a diet higher in fat and increased duration of physical activity, as compared with a control group of students not engaged in the program. These data were crosssectional, so causality cannot be implied. Longitudinal studies are needed to determine whether further sessions might reduce the percentage of fat in this population to the $30 \%$ of calories recommended (US, DHHS, 1995).

Although rewards were given for completed instruments and several additional visits were made by the investigators to encourage students to complete all instruments, missing data prevented regression analysis after testing. Although difficulty in obtaining complete data sets is part of doing research in a school setting, even when working with adults, retaining subjects when doing intervention research is difficult (Prochaska et al., 1992). 
Threats to internal validity exist, as the intervention and control groups were both in the same school setting. However, students in the intervention group did not share classes or teachers with students in the control group, and random assignment of individuals to groups was not possible.

Measures such as body mass index or serum cholesterol level could have been used in this study. However, such measures vary extensively because of a number of developmental, gender, racial, and body composition characteristics (Pittman \& Hayman, 1997) during adolescence, making attribution to the intervention difficult when random assignment is not possible. Use of such measures also would likely have further compounded missing data constraints in this study, as well as added to student time away from class, risk of injury, and study costs. Self-report measures have been deemed adequate for research such as this (Kelder, Perry, Lytle, \& Klepp, 1995; Rockett \& Colditz, 1997).

School-based interventions for low-fat diets have been tested and found to be effective (Contento et al., 1995). However, effective interventions were intense in terms of time commitment and human resources and thus were quite expensive. Because we live in an era of cost reduction, in both health care and education, it is appealing to consider a low-fat diet and exercise intervention that yields positive outcomes in only 4 classroom sessions augmented by peer group strategies.

The previous view that 15 hours of instruction could bring about changes in nutrition knowledge but 50 hours was needed for changes in attitudes and behavior (Connell, Turner, \& Manson, 1985) should be reevaluated in light of these findings. Despite the lack of random assignment, it is likely that the interventions reported in the present study resulted in significant behavior changes, because interventions were appropriate to students' stage of change. We reach this conclusion because the outcome variable, fat in diet, varied predictably by stage of change. We may conclude that less classroom time is needed when the focus of the intervention is appropriate to students' stage of change and those at more advanced stages of change are involved as peer models. 
Although both models have been used extensively in adults, there were no reports in the literature using the Health Promotion Model or the Transtheoretical Model to reduce dietary fat among middle school adolescents. Variance in fat in food accounted for with these models in this study (35\%) was 5 times the $7 \%$ reported in extensive reviews with other social learning theories, such as the Health Belief Model (Contento et al., 1995).

Early adolescence is a developmental time period in which the capacity to reflect on, plan, and make one's own decisions increases. Models tested in this study need to be examined with greater control for similarity of the intervention across classrooms, as well as in a larger number of schools, as would be provided through an Internet format. Further research is also needed to examine effectiveness over time and improvement in physiologic variables, such as body mass index, fitness, and blood cholesterol level, for those with elevated levels. Such research should be given priority, for middle school-aged students are making decisions that will last a lifetime.

\section{References}

G.W. Auld, S.A. Nitzke, J. McNulty, et al. A stage-of-change classification system based on actions and beliefs regarding dietary fat and fiber. American Journal of Health Promotion, 12 (1997), pp. 192-201

T. Baranowski, B. Simons-Morton, P.C. Hooks, et al. A center-based program for exercise change among Black-Americans. Health Education Quarterly, 17 (2) (1990), pp. 179-186

D.B. Connell, R.R. Turner, E.F. Manson. Summary findings of the school health education evaluation: Health promotion effectiveness, implementation, and costs. Journal of School Health, 55 (1985), pp. 316-321

I. Contento, G. Balch, Y. Bronner, et al. The effectiveness of nutrition education and implications for nutrition education policy: A review of research. Journal of Nutrition Education, 27 (1995), pp. 298-369

S.B. Domel, J. Baranowski, S.B. Leonard, et al. A measure of stages of change in fruit and vegetable consumption among fourth and fifthgrade school children: Reliability and validity. Journal of the American College of Nutrition, 15 (1996), pp. 56-64

N. Evans, E. Gilpin, J.J. Farkas. Adolescents' perceptions of their peers' health norms. American Journal of Public Health, 85 (1995), pp. 1064-1069

M.C. Farthing. Current eating patterns of adolescents in the United States. Nutrition Today, 26 (1991), pp. 35-39 permission has been granted for this version to appear in e-Publications@Marquette. Elsevier (WB Saunders) does not grant permission for this article to be further copied/distributed or hosted elsewhere without the express permission from Elsevier (WB Saunders). 
J.J. Foster. Data analysis using SPSS for Windows. Sage, London (2001)

M. Frenn, C.P. Porter. Exercise and nutrition: What do adolescents think is important? Applied Nursing Research, 12 (1999), pp. 181-187

G.I. Feunekes, C. de Graaf, S. Meyboom, W.A. van Staveren. Food choice and fat intake of adolescents and adults: associations of intakes within social networks. Preventive Medicine, 27 (5 Pt 1) (1998), pp. 645-656

A. Garcia, M.A. Broda, M. Frenn, et al.. Gender and developmental differences in exercise beliefs among youth and prediction of their exercise behavior. Journal of School Health, 65 (1995), pp. 213-219

S.L. Gortmaker, K. Peterson, J. Wiecha, et al.. Reducing obesity via a schoolbased interdisciplinary intervention among youth. Archives of Pediatric and Adolescent Medicine, 153 (1999), pp. 409-418

G.W. Greene, S.R. Rossi, G.R. Reed, C. Willey, J.O. Prochaska. Stages of change for reducing dietary fat to $30 \%$ of energy or less. Journal of the American Dietetic Association, 94 (1994), pp. 1105-1110

B.J. Guthrie, C. Loveland-Cherry, M.A. Frey, T.E. Dielman. A theoretical approach to studying health behaviors in adolescents: An at-risk population. Family \& Community Health, 17 (3) (1994), pp. 35-48

J.S. Harrell, S.A. Gansky, R.G. McMurray, et al. School-based interventions improve heart health in children with multiple cardiovascular disease risk factors. Pediatrics, 102 (1998), pp. 371-378

M.N. Hill. AHA president's address-Behavior and biology: The basic sciences for AHA action. Scientific statement 71-0132 3-98. , Presented at the 70th Scientific Sessions of the American Heart Association; Orlando, FL (Nov. 9, 1997)

S.H. Kelder, C.L. Perry, L.A. Lytle, K.I. Klepp. Community-wide youth nutrition education: Long-term outcomes of the Minnesota Heart Health Program. Health Education Research, 10 (1995), pp. 119-131

C.M. Kennedy. Childhood nutrition. J.J. Fitzpatrick (Ed.), Annual review of nursing research, Vol. 16, Springer Publishing Co, Inc, New York (1998), pp. 3-38

R. Lamb, M.S. Joshi. The stage model and processes of change in dietary fat reduction. Journal of Human Nutrition and Dietetics, 9 (1996), pp. 4353

L. Leger, D. Nutbeam. A model for mapping linkages between health and education agencies to improve school health. Journal of School Health, 70 (2000), pp. 45-50

M. Lewis, J. Brun, H. Talmage, S. Rasher. Teenagers and food choices: The impact of nutrition education. Journal of Nutrition Education, 20 (1988), pp. 336-340

R.V. Luepker, C.L. Perry, S.M. McKinlay, et al. Outcomes of a field trial to improve children's dietary patterns and physical activity: The Child and

Journal of Pediatric Nursing, Vol 18, No. 1 (2003, February): pg. 36-45. DOI. This article is (c) Elsevier (WB Saunders) and permission has been granted for this version to appear in e-Publications@Marquette. Elsevier (WB Saunders) does not grant permission for this article to be further copied/distributed or hosted elsewhere without the express permission from Elsevier (WB Saunders). 
NOT THE PUBLISHED VERSION; this is the author's final, peer-reviewed manuscript. The published version may be accessed by following the link in the citation at the bottom of the page.

Adolescent Trial for Cardiovascular Health (CATCH). JAMA, 275 (1996), pp. 768-776

W. McCarthy, M. Newcomb. Two dimensions of perceived self-efficacy: Cognitive control and behavioral coping ability. R. Schwarzer (Ed.), Self-efficacy: Thought control of actionHemisphere Publishing Corp, Washington, DC (1992), pp. 39-64

J.C. Meininger. Primary prevention of cardiovascular disease risk factors: Review and implications for population-based practice. Advance Practice Nurse Quarterly, 3 (1997), pp. 70-79

National Center for Health Statistics. Healthy People 2000 review, 1998-99. Public Health Service, Hyattsville, MD (1999)

National Center for Health Statistics, Centers for Disease Control and Prevention. Prevalence of overweight and obesity among children and adolescents: United States, 1999. Retrieved December 2, 2002 from http://www.cdc.gov/nchs/products/pubs/pubd/hestats/over99fig 1.htm (1999)

National Center for Health Statistics. Healthy People 2000 final review, 2000. Public Health Service, Hyattsville, MD (2001)

N.J. Pender. Health promotion in nursing practice. (3rd ed)Appleton \& Lange, Stamford, CT (1996)

K.P. Pittman, L.I. Hayman. Determinants of risk for cardiovascular disease during school-age/adolescent transition. Progress in Cardiovascular Nursing, 12 (4) (1997), pp. 12-22

J.O. Prochaska, C.C. DiClemente, J.C. Norcross. In search of how people change. American Psychologist, 47 (1992), pp. 1102-1114

J.O. Prochaska, J.C. Norcross, J.L. Fowler, M.J. Follick, D.B. Abrams. Attendance and outcome in a work site weight control program: Processes and stages of change as process and predictor variables. Addictive Behaviors, 17 (1992), pp. 35-45

J.O. Prochaska, W.F. Velicer, J.S. Rossi, et al. Stages of change and decisional balance for 12 problem behaviors. Health Psychology, 13 (1994), pp. $39-46$

M.H. Read. Age, dietary behaviors and the stages of change model. American Journal of Health Promotion, 20 (1996), pp. 417-424

H. Rockett, G.A. Colditz. Assessing diets of children and adolescents. American Journal of Clinical Nutrition, 65 (Suppl) (1997), pp. 1116S$1122 \mathrm{~S}$

S.R. Rossi, J.R. Rossi, L.M. Rossi-Delprete, J.O. Prochaska, S.W. Banspach, R.A. Carleton. A process of change model for weight control for participants in community-based weight loss programs. International Journal of the Addictions, 29 (2) (1994), pp. 161-217

A. Steptoe, S. Wijetunge, S. Doherty, J. Wardle. Stages of change for dietary fat reduction: Associations with food intake, decisional balance and

Journal of Pediatric Nursing, Vol 18, No. 1 (2003, February): pg. 36-45. DOI. This article is (C) Elsevier (WB Saunders) and permission has been granted for this version to appear in e-Publications@Marquette. Elsevier (WB Saunders) does not grant permission for this article to be further copied/distributed or hosted elsewhere without the express permission from Elsevier (WB Saunders). 
motives for food choice. Health Education Journal, 55 (1996), pp. 108122

L. Taylor. Achieving coordinated mental health programs in schools. Journal of School Health, 70 (2000), pp. 169-170

US Department of Health and Human Services, Public Health Service. Healthy People 2000 midcourse review and 1995 revisions. US Government Printing Office, Washington, DC (1995)

US Department of Health and Human Services, Office of the Surgeon General. The Surgeon General's call to action to prevent and decrease overweight and obesity 2001. US Department of Health and Human Services, Public Health Service, Office of the Surgeon General. US Government Printing Office, Rockville, MD (2001)

W.F. Velicer, C.C. DiClemente, J.S. Rossi, J.O. Prochaska. Relapse situations and self-efficacy: An integrative model. Addictive Behaviors, 15 (1990), pp. 271-283

B. Velsor-Friedrich. Adolescent school health. Journal of Pediatric Nursing, 16 (2001), pp. 194-196

J. Williams. Competition spurs MPS budget plans as district vies with alternatives, Brown seeks to improve achievement. Milwaukee Journal Sentinel (Retrieved December 2, 2002) from http://www.jsonline.com/news/feb99/0224mps.asp (1999, February 24)

World Health Organization. The WHO cross-national study on health behavior in school-aged children from 28 countries. Findings from the United States. Journal of School Health, 70 (6) (2000), pp. 227-228

*Partial support for preliminary work in this project was awarded to M.F. through the Institutional Postdoctoral Fellowship in Health Promotion and Disease Prevention (Nola Pender, PhD, RN, FAAN, primary mentor), University of Michigan, and to M.F. and S.M. through the Graduate School, Marquette University.

**Address correspondence and reprint requests to Marilyn Frenn, PhD, RN, Marquette University, College of Nursing, PO Box 1881, Milwaukee, WI 53201-1881. 